PROBLEMS

OF EDUCATION IN THE $21^{\text {st }}$ CENTURY Vol. 79, No. 5, 2021

804

\title{
INCLUSIVE DIAGNOSTICS AND STIMULATION OF SOCIALLY DISADVANTAGED CHILDREN OF A PRE-SCHOOL AGE: EXPERIMENTAL VERIFICATION
}

\author{
Viera Šilonová, Vladimír Klein \\ Prešov University in Prešov, Slovakia \\ E-mail: vierasilonova@gmail.com, vladimir.klein@unipo.sk
}

Ivana Rochovská

Catholic University in Ruzomberok, Slovakia

E-mail: ikrupova@gmail.com

\begin{abstract}
The research focuses on the diagnostics and stimulation of socially disadvantaged children of a preschool age, which is a crucial component of inclusive education. The aim of the research was to experimentally verify through input and output orientation diagnostics the effectiveness of the stimulation program for 5 to 6 year old socially disadvantaged children in kindergartens. The results of the input and output orientation screening of 5 to 6 year old children from the experimental and control groups were analysed. Furthermore, the effectiveness of the stimulation program intended for the training of areas of deficits of partial functions and symptoms in the experimental group was verified, and conclusions and recommendations for pedagogical theory and practice in the area of inclusive approaches at the preprimary stage of the school system were formulated. The research demonstrated that the experimental group of children achieved statistically significantly better results in the post-test, focused on the area of symptoms measured by the t-test, than the control group. It was also confirmed that both groups of socially disadvantaged children (control and experimental) achieved statistically significantly better results in the post-test, focused on the area of deficits of partial functions, than in the pre-test.
\end{abstract}

Keywords: inclusive diagnostics, inclusive education, pre-school age, socially disadvantaged children

\section{Introduction}

It is well known that children, educated in a segregated group, often identify themselves with belonging to second-rate people, which contributes to the conservation of a divided society. Research and praxis have also shown that an ethnically and socially mixed group is a much more suitable place to acquire human capital (social and cultural) than a homogeneous environment. Human capital also depends on the number of relationships with people of other origins, other cultures and other social statuses, between whom there is trust and functioning rules. The greater the heterogeneity, the more able a person is to integrate into society.

Education is the most important factor in the development of children, especially among those who come from a socially disadvantaged background. The environment does not provide them with enough stimuli for the optimal and healthy development of all aspects of their personality (Bakken at al., 2017). The results of neuroscientific research have clearly shown 
Viera ŠILONOVÁ, Vladimír KLEIN, Ivana ROCHOVSKÁ. Inclusive diagnostics and stimulation of socially disadvantaged children of a pre-school age: Experimental verification

PROBLEMS

OF EDUCATION

IN THE $21^{\text {st }}$ CENTURY

Vol. 79, No. 5, 2021

that a disadvantaged environment has a negative impact on the development of the child's brain, and especially in areas responsible for mental, social and emotional development, language development, memory, learning, behaviour and motor skills (Hanson et al., 2011). Deficiencies caused by an unequal environment will begin to grow and the differences between children will deepen after entering primary education. The child will be accompanied by failure during all of the school years and throughout the entire adult life (Magnuson \& Shager, 2010). For a child from a socially disadvantaged environment, the kindergarten is where his knowledge and skills can develop optimally and harmoniously under the professional guidance and educational work of a teacher. The aforementioned ideas highlight the need for an inclusive education.

An important part of the creation of an inclusive education is the application of inclusive diagnostics of children of a pre-school age and the development stimulation of 5 to 6 year old children before entering primary school, which can be perceived as prevention before the unauthorised placement of these children into special school systems for pupils with mental disabilities. For this reason, research is focused on the diagnostic process and development stimulation of socially disadvantaged children of a pre-school age, which represents a crucial component of inclusive education.

\section{Theoretical Starting Point of the Studied Issue}

Inclusive education within the conditions of a kindergarten is addressed by Hul'ová et al., who state that "... in terms of the inclusion of children into kindergartens, the trend is an inclusive education supporting the diversity and development of the child's personality without any comparison with other children. Also in Slovakia, the creation of current curricular documents for pre-primary education emphasises an interactionist approach (as opposed to the more extreme approaches of empiricism or nativism), preferring a democratic style, mutual respect, trust and partnership communication. The adult is not the one who knows everything and the child the one to learn everything from him, but he is in the role of facilitator and a partner of the child, they share common activities, they gain experiences, which are the basis for the acquisition of knowledge, skills, experience, attitudes, values, etc." (Hul'ová et al. 2018, p. 203).

The whole world is aware of the need to educate children from socially disadvantaged backgrounds and their gradual inclusion into society. Individual countries are working to improve availability and access to a pre-primary education.

According to UNESCO (2009), inclusive schools must use such learning techniques which react to individual differences and therefore benefit all children. Inclusive schools have the power to change attitudes towards diversity and form the basis for a fairer and nondiscriminatory society.

The difference between special and inclusive education lies mainly in the perception of the cause of difficulties with which a child may encounter in education and thus in the perception of the concept of special upbringing-educational needs (Ainscow \& César, 2006).

Schröder (2000) has described a new emphasis in diagnostics, which brings a departure from "deficit pedagogy" and sees the solution in supporting the child through proper inclusion in the school system. In this context, a new concept has created - supportive diagnostics (Förderdiagnostik). In connection with this, Šilonová and Klein (2018) have also talked about so-called dynamic diagnostics. It is an approach connecting elements of diagnostics and intervention.

Other studies are also relevant in connection with the subject matter, e.g., Šilonová and Klein (2018); Klein et al. (2019); Ishchenko et al., (2020); Klein and Hladush (2019); Šilonová et al. (2020); Nikolenko and Šilonová (2020). 
Viera ŠILONOVÁ, Vladimír KLEIN, Ivana ROCHOVSKÁ. Inclusive diagnostics and stimulation of socially disadvantaged children of a pre-school age: Experimental verification

PROBLEMS

OF EDUCATION IN THE $21^{\text {st }}$ CENTURY Vol. 79 , No. 5,202

806

The impetus for the focus of this research in the field of diagnostics and the stimulation of children of a pre-school age was an acquaintance with the ideas of Brigitte Sindelar (2009a, 2009 b) - the author of a methodology focused on deficits of partial functions. Sindelar (2009a, $2009 \mathrm{~b}, 2014)$ identified not only the weaknesses, but also the strengths of the child. This means that her methodology focuses on what the child knows, and not just on what he does not know. According to Sindelar (2009a), partial performances can be perceived as "partial functions of a holistic information processing network, which represent specific modal and intermodal processes of attention, perception and memory, as well as their serial integration. Information processing, in turn, is a prerequisite for complex cognitive performance as well as for executive functions, such as the mentalisation function." These basic functions determine the proper development of speech, writing, reading and counting.

Within the diagnostic-stimulation programs for 5 to 6 year old children of kindergartens, inspired by the Sindelar methodology, the diagnostic and training part of screening the partial functions of children was focused on identifying basal functions, which condition the correct harmonious development of children of a pre-school age (graphomotor skills, speech, mathematical abilities etc.).

\section{Researched Issue}

The key topic of research was the diagnostics and stimulation of socially disadvantaged children of a pre-school age. The current perception of diagnostics reflects the changes which are visible in the perception and approach to socially disadvantaged children, in relation to integration and inclusive tendencies. An emphasis is placed on the area in which the individual excels, on which it is possible to build in connection with further intervention. The individual is perceived as a personality with a potential for further development. On the basis of the theoretical background, the research problem became a question of whether the use of a stimulation program in socially disadvantaged children from the experimental group will contribute to their better results in the output screening.

\section{The Aim and Hypotheses of the Research}

The aim of the research was to experimentally verify through input and output orientation diagnostics the effectiveness of the stimulation program for 5 to 6 year old socially disadvantaged children in kindergartens. In connection with this, the following objectives were formulated:

1. Analyse the results of the input and output orientation investigation of 5 to 6 year old socially disadvantaged children from the experimental group.

2. Analyse the results of the input and output orientation investigation of 5 to 6 year old socially disadvantaged children from the control group.

3. Compare the results of the input and output orientation investigation between 5 to 6 year old socially disadvantaged children from the experimental group and from the control group.

4. Verify the effectiveness of the stimulation program intended for the training of the areas of deficits of partial functions and symptoms in the experimental group.

5. Formulate conclusions and recommendations for pedagogical theory and praxis in the area of inclusive approaches at the pre-primary stage of the school system.

On the basis of the theoretical background, field experience, the research problem and the aims of the research, two hypotheses were formulated $\left(\mathrm{H}_{1}\right.$ and $\left.\mathrm{H}_{2}\right)$ and for each of them two sub-hypotheses $\left(\mathrm{SH}_{1.1}, \mathrm{SH}_{1.2}, \mathrm{SH}_{2.1}\right.$ and $\left.\mathrm{SH}_{2.2}\right)$, which relate to the difference between the two groups of socially disadvantaged children. 
Viera ŠILONOVÁ, Vladimír KLEIN, Ivana ROCHOVSKÁ. Inclusive diagnostics and stimulation of socially disadvantaged children of a pre-school age: Experimental verification

$\mathrm{H}_{1}$ : Children from the experimental group, who completed the stimulation program, will achieve better results than children from the control group, who did not take part in the stimulation program.

$\mathrm{SH}_{1.1}$ : Children from the experimental group will have better results in the post-test focused on the area of deficits of partial functions than children from the control group.

$\mathrm{SH}_{1.2}$ : Children from the experimental group will have better results in the post-test focused on the area of symptoms than children from the control group.

$\mathrm{H}_{2}$ : Children in each group will have better results in the post-test in at least one area than in the pre-test.

$\mathrm{SH}_{2.1}$ : Children in each group will have better results in at least one area in the post-test, focusing on the area of deficits of partial functions, than in the pre-test.

$\mathrm{SH}_{22}$ : Children in each group will have better results in at least one area in the post-test, focusing on the area of symptoms, than in the pre-test.

\section{Research Methodology}

\section{General Background}

Experimental research was carried out in Slovakia from September 2019 to June 2020 - the diagnostics and stimulation of children of a pre-school age, which was part of a national project entitled "Creating an inclusive environment in the kindergarten and inclusive approaches in diagnostics and stimulation of the development of socially disadvantaged children". The project focused on the creation and validation of an instrument for the evaluation of kindergartens in the area of inclusion; verification of the effectiveness of the Stimulation Program for Socially Disadvantaged Children of a Pre-School Age; and finding out the opinions of pedagogical and professional employees on the effectiveness and efficiency of the methodology of the Stimulation Program for Socially Disadvantaged Children of a Pre-school Age.

\section{Instruments and Procedures}

The real experiment was chosen. The selection of participants for the experimental and control groups took place in a random way. Screening (orientation diagnostics of 5 to 6 year old socially disadvantaged children) took place on the premises of kindergartens over two periods, according to the following timetable: September/October 2019 - input orientation screening and May/June 2020 - output orientation screening. The diagnostic instrument, Manuál k depistáži (Manual for Screening) (Šilonová et al., 2018), was used.

Tables 1, 2 and 3 list the areas and items of the diagnostic and stimulation instrument which are identical to the areas from the Manual for screening for children of a pre-school age from socially disadvantaged backgrounds. Screening 1 is focused on the area of deficits of partial functions and Screening 2 on the area of symptoms. 
Viera ŠILONOVÁ, Vladimír KLEIN, Ivana ROCHOVSKÁ. Inclusive diagnostics and stimulation of socially disadvantaged children of a pre-school age: Experimental verification

PROBLEMS

OF EDUCATION

IN THE $21^{\text {st }}$ CENTURY

Vol. 79 , No. 5, 2021

808

Table 1

Areas and Items of the Diagnostic and Stimulation Instrument 5-6 - Group Screening

\begin{tabular}{lll}
\hline Areas and items & Score & Criteria \\
\hline $\begin{array}{l}\text { The drawing of a person } \\
\text { (grade 1 - 5) }\end{array}$ & Grade 1-5 & Overall qualitative rendering \\
Behaviour during group screening & Max. 5 points & $\begin{array}{l}\text { Unable to separate from loved ones/acquaintances } \\
\text { Distracted/inattentive } \\
\text { Dependent/uncertain } \\
\end{array}$ \\
& $\begin{array}{l}\text { Emotionally out of tune } \\
\text { Negativistic }\end{array}$ \\
$\begin{array}{l}\text { Does the child come from a socially } \\
\text { disadvantaged background? }\end{array}$ & Yes/No \\
$\begin{array}{l}\text { Has a stimulation program been } \\
\text { implemented with the child? }\end{array}$ & & Yes/No \\
\hline
\end{tabular}

Table 2

Areas and Items of the Diagnostic and Stimulation Instrument 5-6 - Screening 1

\begin{tabular}{ll}
\hline Areas and items & Number of errors \\
\hline Visual differentiation of the figure and the background & Max. 6 errors \\
Visual differentiation & Max. 6 errors \\
Visual memory & Max. 6 errors \\
Auditory differentiation of the figure and the background & Max. 12 errors \\
Auditory differentiation & Max. 6 errors \\
Auditory memory & Max. 7 errors \\
Tactile-kinesthetic perception & Max. 6 errors \\
Body diagram & Max. 4 errors \\
Intermodality: visual-auditory & Max. 9 errors \\
Intermodality: auditory-visual & Max. 9 errors \\
Visual seriality & Max. 5 errors \\
Auditory seriality & Max. 5 errors \\
\hline
\end{tabular}

\section{Table 3}

Areas and Items of the Diagnostic and Stimulation Instrument 5-6 - Screening 2

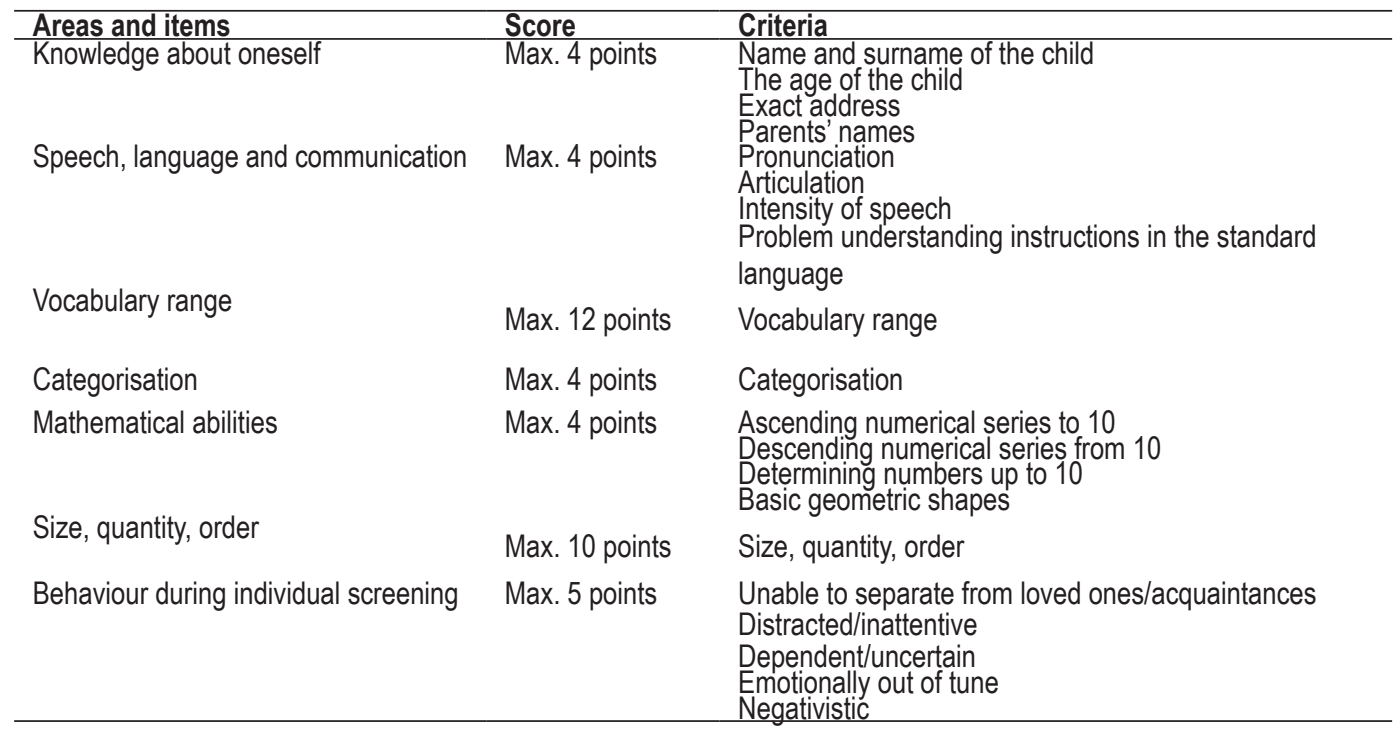


Viera ŠILONOVÁ, Vladimír KLEIN, Ivana ROCHOVSKÁ. Inclusive diagnostics and stimulation of socially disadvantaged children of a pre-school age: Experimental verification

PROBLEMS

OF EDUCATION

IN THE $21^{\text {st }}$ CENTURY

Vol. 79, No. 5, 2021

The research was carried out as a comparative experiment. It worked with two groups: the participants of the experimental group were exposed to intervention by the stimulation program, while among participants from the control group, intervention by the stimulation program has not been implemented. The control group participated in standard education within the kindergarten. All post-test procedures were analogous to pre-test procedures.

\section{Sample Selection}

1634 children from 92 kindergartens took part in the input screening as part of a national project. From the stated number of respondents, 16 participants - experimental persons $(8$ boys and 8 girls) were randomly selected, who formed the experimental group. These were children of a pre-school age, from socially disadvantaged backgrounds. Participants from the experimental group completed the input screening, stimulation (Šilonová et al., 2018) experimental intervention and output investigation carried out by pedagogical employees (the school's special pedagogues) and professional staff of kindergartens involved in a national project.

The input orientation screening was also carried out in kindergartens which were not involved in the national project. 102 children from socially disadvantaged backgrounds took part in the input screening. From the stated number of children, 16 participants - control persons ( 8 boys and 8 girls) were randomly selected into the control group. An input and output screening were carried out with the participants from the control group.

A comparison of the pre-test results of the experimental and control groups by a Pearson's Chi-square test is presented in Table 4.

\section{Table 4}

Pre-test Results of the Experimental and Control Group (Pearson's Chi-Square test)

\begin{tabular}{|c|c|c|c|}
\hline Area & $\chi^{2}$ & $d f$ & $\mathrm{p}$ \\
\hline $\begin{array}{l}\text { Group screening - behaviour: Unable to separate from loved } \\
\text { ones/acquaintances }\end{array}$ & 28.571 & 1 & $<.0001$ \\
\hline Group screening - behaviour: Distracted/inattentive & 37.037 & 1 & $<.0001$ \\
\hline Group screening - behaviour: Dependent/uncertain & 37.037 & 1 & $<.0001$ \\
\hline Group screening - behaviour: Emotionally out of tune & 28.571 & 1 & $<.0001$ \\
\hline Group screening - behaviour: Negativistic & 7.143 & 1 & .005 \\
\hline Knowledge about oneself - Name and surname & 5.128 & 1 & .028 \\
\hline Knowledge about oneself - Age & 4.167 & 1 & .048 \\
\hline Knowledge about oneself - Exact address & 0.000 & 1 & 1 \\
\hline Knowledge about oneself - Parents' names & 0.000 & 1 & 1 \\
\hline Speech, language and communication - Pronunciation & 0.784 & 1 & .395 \\
\hline Speech, language and communication - Articulation & 13.333 & 1 & .0002 \\
\hline Speech, language and communication - Intensity of speech & 3.125 & 1 & .089 \\
\hline $\begin{array}{l}\text { Speech, language and communication - Problem with } \\
\text { understanding instructions in the standard language }\end{array}$ & 0.866 & 1 & .323 \\
\hline Mathematical abilities - Ascending numerical series to 10 & 12.698 & 1 & .0004 \\
\hline Mathematical abilities - Descending numerical series from 10 & 0.000 & 1 & 1 \\
\hline Mathematical abilities - Determining numbers up to 10 & 2.299 & 1 & .096 \\
\hline Mathematical abilities - Basic geometric shapes & 7.143 & 1 & .005 \\
\hline $\begin{array}{l}\text { Individual screening - behaviour: Unable to separate from } \\
\text { loved ones/acquaintances }\end{array}$ & 28.571 & 1 & $<.0001$ \\
\hline Individual screening - behaviour: Distracted/inattentive & 37.500 & 1 & $<.0001$ \\
\hline Individual screening - behaviour: Dependent/uncertain & 0.966 & 1 & .345 \\
\hline Individual screening - behaviour: Emotionally out of tune & 13.333 & 1 & .0002 \\
\hline Individual screening - behaviour: Negativistic & 2.299 & 1 & .096 \\
\hline
\end{tabular}


Viera ŠILONOVÁ, Vladimír KLEIN, Ivana ROCHOVSKÁ. Inclusive diagnostics and stimulation of socially disadvantaged children of a pre-school age: Experimental verification

PROBLEMS

OF EDUCATION

IN THE $21^{\text {st }}$ CENTURY

Vol. 79 , No. 5,202

810

An analysis of the pre-test results of the experimental and control groups shows that from the 22 areas measured by the Pearson's Chi-square test, there was no statistically significant difference at input in 9 items: Knowledge about oneself - exact address; Knowledge about oneself - parents' names; Speech, language and communication - pronunciation; Speech, language and communication - intensity of speech; Speech, language and communication - a problem understanding instructions in the standard language; Mathematical abilities descending numerical series from 10; Mathematical abilities - determining numbers up to 10; Behaviour during individual screening - dependent/uncertain; Behaviour during individual screening - negativistic.

The experimental group of children had statistically significantly better results in the pretest than the control group in 10 items: Behaviour during individual screening - unable to separate from loved ones/acquaintances; Behaviour during individual screening - distracted/inattentive; Behaviour during individual screening - dependent/uncertain; Behaviour during individual screening - emotionally out of tune and negativistic; Speech, language and communication articulation; Mathematical abilities - ascending numerical series to 10; Mathematical abilities basic geometric shapes; Behaviour during individual screening - unable to separate from loved ones/acquaintances; Behaviour during individual screening - dependent/uncertain; Behaviour during individual screening - emotionally out of tune.

The experimental group of children had statistically significantly worse results in the pre-test than the control group in 2 items: Knowledge about oneself - name and surname; Knowledge about oneself - age.

By comparing the pre-test results of the experimental and control groups (Pearson's Chisquare test), there are no statistically significant differences, which means that both groups can be considered as the same.

The processing of the results in terms of their significance within individual areas was carried out by means of a $t$-test for two independent selections. Null hypotheses about the equality of mean values, which were tested against the two-tailed alternative hypothesis at a significance level of 0.05 , were formulated. An overview of mean values and standard deviations measured in the individual areas is presented in Table 5. 
Viera ŠILONOVÁ, Vladimír KLEIN, Ivana ROCHOVSKÁ. Inclusive diagnostics and stimulation of socially disadvantaged children of a pre-school age: Experimental verification

Table 5

Pre-test Results of the Experimental and Control Groups (t-test)

\begin{tabular}{|c|c|c|c|c|c|c|}
\hline Area & & $M$ & $t$ & $p$ & & $S D$ \\
\hline & Control & Experimental & & & Control & Experimental \\
\hline $\begin{array}{l}\text { The drawing of a person } \\
\text { (grade 1-5) }\end{array}$ & 2.63 & 1.81 & 1.777 & .086 & 1.36 & 1.22 \\
\hline $\begin{array}{l}\text { Visual differentiation of the } \\
\text { figure and the background, } \\
\text { only the picture with hens } \\
\text { (max. } 6 \text { errors) }\end{array}$ & 1.06 & 1.56 & -0.648 & .522 & 2.02 & 2.34 \\
\hline $\begin{array}{l}\text { Visual differentiation (max. } 6 \\
\text { errors) }\end{array}$ & 4.19 & 3.81 & 0.542 & .592 & 1.91 & 2.01 \\
\hline Visual memory (max. 6 errors) & 3.94 & 3.69 & 0.356 & .724 & 1.84 & 2.12 \\
\hline $\begin{array}{l}\text { Auditory differentiation of the } \\
\text { figure and the background } \\
\text { (max. } 12 \text { errors) }\end{array}$ & 10.25 & 9.69 & 0.481 & .634 & 3.57 & 3.03 \\
\hline $\begin{array}{l}\text { Auditory differentiation (max. } \\
6 \text { errors) }\end{array}$ & 4.00 & 3.94 & 0.076 & .940 & 2.37 & 2.26 \\
\hline $\begin{array}{l}\text { Auditory memory (max. } 7 \\
\text { errors) }\end{array}$ & 3.56 & 3.81 & -0.312 & .757 & 1.93 & 2.56 \\
\hline $\begin{array}{l}\text { Tactile-kinesthetic perception } \\
\text { (max. } 6 \text { errors) }\end{array}$ & 3.75 & 2.63 & 1.513 & .141 & 2.32 & 1.86 \\
\hline Body diagram (max. 4 errors) & 3.00 & 2.75 & 0.532 & .599 & 1.21 & 1.44 \\
\hline $\begin{array}{l}\text { Intermodality: visual-auditory } \\
\text { (max. } 9 \text { errors) }\end{array}$ & 4.25 & 4.00 & 0.178 & .860 & 4.43 & 3.44 \\
\hline $\begin{array}{l}\text { Intermodality: auditory-visual } \\
\text { (max. } 9 \text { errors) }\end{array}$ & 5.69 & 5.56 & 0.100 & .921 & 3.75 & 3.29 \\
\hline Visual seriality (max. 5 errors) & 3.88 & 3.44 & 0.630 & .533 & 2.06 & 1.86 \\
\hline $\begin{array}{l}\text { Auditory seriality (max. } 5 \\
\text { errors) }\end{array}$ & 1.63 & 1.63 & 0.000 & 1 & 2.36 & 2.13 \\
\hline Vocabulary range & 8.81 & 8.56 & 0.292 & .773 & 3.06 & 1.55 \\
\hline Categorisation & 0.63 & 0.81 & -0.497 & .623 & 1.20 & 0.91 \\
\hline Size, quantity, order & 3.75 & 3.00 & 0.859 & .397 & 2.74 & 2.16 \\
\hline
\end{tabular}

In the pre-test, there were no statistically significant differences between the two groups of children. This means that the recorded responses of the children in the individual items were similar. From the above, it follows that despite the differences between the experimental and control groups (mostly in favour of the control group), within the pre-test there are no statistically significant differences, hence in these characteristics both groups can be considered the same.

\section{Data Analysis}

To verify hypothesis $\mathrm{H}_{1}$, including the sub-hypotheses, a $t$-test was used. To verify hypothesis $\mathrm{H}_{2}$, including the sub-hypotheses, for items where there was more than binary scoring, a paired $t$-test was used. For binary-scored items, for both hypotheses and their subhypotheses, a Pearson's Chi-square test (for a four-field table) was used. 
Viera ŠILONOVÁ, Vladimír KLEIN, Ivana ROCHOVSKÁ. Inclusive diagnostics and stimulation of socially disadvantaged children of a pre-school age: Experimental verification

OF EDUCA

IN THE $21^{\text {st }}$ CENTURY Vol. 79 , No. 5, 2021

812

\section{Research Results}

\section{Verification of Hypothesis $H_{1}$}

In hypothesis $\mathrm{H}_{1}$, an assumption was formulated that children from the experimental group, who completed the stimulation program, will achieve better results than children from the control group, who did not complete the stimulation program.

Descriptive statistics of the distributed data of the experimental group and the control group are reported in Tables 6,7 and 8 .

\section{Table 6}

Post-test Results of the Experimental and Control Groups (t-test)

\begin{tabular}{|c|c|c|c|c|c|c|}
\hline $\begin{array}{l}\text { Area } \\
\text { - deficits of partial functions }\end{array}$ & & $M$ & $t$ & $p$ & & $S D$ \\
\hline & Control & Experimental & & & Control & Experimental \\
\hline $\begin{array}{l}\text { Visual differentiation of the figure } \\
\text { and the background, only the } \\
\text { picture with hens (max. } 6 \text { errors) }\end{array}$ & 0.44 & 0.25 & 0.478 & .636 & 1.50 & 0.45 \\
\hline Visual differentiation (max. 6 errors) & 2.69 & 1.44 & 2.096 & .045 & 2.09 & 1.15 \\
\hline Visual memory (max. 6 errors) ${ }^{*}$ & 3.13 & 3.00 & 0.182 & .857 & 1.78 & 2.10 \\
\hline $\begin{array}{l}\text { Auditory differentiation of the figure } \\
\text { and the background (max. } 12 \\
\text { errors) }\end{array}$ & 9.25 & 5.00 & 4.533 & $<.0001$ & 2.96 & 2.31 \\
\hline $\begin{array}{l}\text { Auditory differentiation (max. } 6 \\
\text { errors) }\end{array}$ & 3.25 & 1.81 & 2.129 & .042 & 1.95 & 1.87 \\
\hline Auditory memory (max. 7 errors) ${ }^{*}$ & 1.69 & 1.44 & 0.563 & .578 & 1.35 & 1.15 \\
\hline $\begin{array}{l}\text { Tactile-kinesthetic perception (max. } \\
6 \text { errors) }\end{array}$ & 3.13 & 1.31 & 2.973 & .006 & 2.13 & 1.20 \\
\hline Body diagram (max. 4 errors) & 3.00 & 1.38 & 3.806 & .001 & 1.15 & 1.26 \\
\hline $\begin{array}{l}\text { Intermodality: visual-auditory (max. } \\
9 \text { errors)* }\end{array}$ & 1.13 & 0.44 & 1.056 & .299 & 2.28 & 1.26 \\
\hline $\begin{array}{l}\text { Intermodality: auditory-visual (max. } \\
9 \text { errors) }\end{array}$ & 4.19 & 1.44 & 2.692 & .011 & 3.60 & 1.93 \\
\hline Visual seriality (max. 5 errors) & 2.63 & 0.94 & 2.236 & .033 & 2.45 & 1.77 \\
\hline Auditory seriality (max. 5 errors) ${ }^{*}$ & 0.81 & 0.31 & 1.169 & .251 & 1.56 & 0.70 \\
\hline
\end{tabular}

* There is no difference between the groups in the post-test.

Through the calculated $t$-statistic (2.096), at a level of significance of 0.045 , a statistically significant difference was found between the results in the post-test of the experimental and control groups of children. In the output measurement, the experimental group achieved in the area of Visual Differentiation a lower number of errors $(M=1.44)$ than the control group $(M=$ 2.69). 
Viera ŠILONOVÁ, Vladimír KLEIN, Ivana ROCHOVSKÁ. Inclusive diagnostics and stimulation of socially disadvantaged children of a pre-school age: Experimental verification

The experimental group achieved a lower number of errors in the area of Auditory differentiation of the figure and the background $(M=5.00)$ than the control group $(M=$ 9.25). In the post-test, a statistically significant difference between the groups in favour of the experimental group was confirmed $(t=4.533, d f=1, p<.0001)$.

A statistically significant difference between the results in the post-test of the experimental and control groups of children was also found in the other measured areas through the calculated $t$-statistic (2.129), at a level of significance of 0.042 . In the post-test, the experimental group achieved in the area of Auditory differentiation a lower number of errors $(M=1.81)$ than the control group $(M=3.25)$.

Through the calculated $t$-statistic (2.973), at a level of significance of 0.006 , a statistically significant difference was found between the results in the post-test of the experimental and control groups of children. In the output measurement, the experimental group achieved in the area of Tactile-kinesthetic perception a lower number of errors $(M=1.31)$ than the control group $(M=3.13)$.

The results in the post-test were statistically significantly better in the experimental group of children in the other three areas: Body diagram - through the t-statistic (3.806), at a level of significance of 0.001 , a statistically significant difference is presented between the monitored groups. In the post-test, the experimental group achieved a lower number of errors $(M=1.38)$ than the control group $(M=3.00)$. Intermodality: auditory-visual - through the t-statistic (2.692), at a level of significance of 0.011 , a statistically significant difference was found between the results in the post-test of the experimental group and the control group of children. In the output measurement, the experimental group achieved a lower number of errors in this area $(M=1.44)$ than the control group $(M=4.19)$. Visual seriality: Through the calculated t-statistic $(2.236)$, at a significance level of 0.045 , a statistically significant difference was found between the results in the post-test of the experimental and control groups of children. In the output measurement, the experimental group achieved in the area of Visual seriality a lower number of errors $(M=$ $0.94)$ than the control group $(M=2.63)$.

The total deficits of partial functions measured by the $t$-test was 12 . Of the aforementioned number, 5 areas are listed in which there is no statistically significant difference between the two groups in the post-test. Statistically significantly better results in favour of the experimental group of children were recorded in 7 areas. With the intentions of the above, the subhypothesis $\mathrm{SH}_{1.1}$ was adopted.

Four items belonging to the area of symptoms were measured by a $t$-test. From these, two areas were statistically significant in favour of the experimental group. There was no statistically significant difference between the two groups in the other two areas.

\section{Table 7}

Post-test Results of the Experimental and Control Groups (t-test)

\begin{tabular}{lcccccc}
\hline Area - symptoms & \multicolumn{2}{c}{$\boldsymbol{M}$} & $\boldsymbol{t}$ & $\boldsymbol{p}$ & \multicolumn{2}{c}{$\boldsymbol{S D}$} \\
\hline & Control & Experimental & & & Control & Experimental \\
The drawing of a person & 3.69 & 2.69 & 2.702 & .011 & 0.95 & 0.011 \\
(grade 1 - 5) & 9.31 & 9.81 & -0.441 & .662 & 3.79 & 2.48 \\
Vocabulary range* $^{*}$ & 1.56 & 2.25 & -1.364 & .183 & 1.21 & 1.61 \\
Categorisation* $^{*}$ & 4.50 & 6.88 & -2.744 & .010 & 2.99 & 1.75 \\
Size, quantity, order & & &
\end{tabular}

* There is no difference between the groups in the post-test. 
Viera ŠILONOVÁ, Vladimír KLEIN, Ivana ROCHOVSKÁ. Inclusive diagnostics and stimulation of socially disadvantaged children of a pre-school age: Experimental verification

PROBLEMS

OF EDUCATION

IN THE $21^{\text {st }}$ CENTURY

Vol. 79 , No. 5,202

Through the calculated $t$-statistic (2.702), at a level of significance of 0.011 , a statistically significant difference was found between the results in the post-test of the experimental and control groups of children. In the output measurement, the experimental group achieved in the area of The drawing of a person a better grade $(M=2.69)$ than the control group $(M=3.69)$.

The experimental group achieved in the area of Size, quantity, order a lower number of errors $(M=6.88)$ than the control group $(M=2.99)$. In the post-test, a statistically significant difference between the groups in favour of the experimental group was confirmed $(t=4.533$, $d f=1, p<.0001)$.

It was confirmed that the experimental group of children achieved statistically significantly better results in the post-test, focused on the area of symptoms measured by the $t$-test, than the control group.

Table 8

An Evaluation of the Post-test Results of the Experimental and Control Groups (Pearson's Chi-square test)

\begin{tabular}{|c|c|c|c|}
\hline Area & $\chi^{2}$ & $d f$ & $p$ \\
\hline $\begin{array}{l}\text { Group screening: Unable to separate from loved ones/ } \\
\text { acquaintances* }\end{array}$ & 0.000 & 1 & 1 \\
\hline Group screening: Distracted/inattentive & 20.690 & 1 & $<.0001$ \\
\hline Group screening: Dependent/uncertain & 28.571 & 1 & $<.0001$ \\
\hline Group screening: Emotionally out of tune & 6.452 & 1 & .013 \\
\hline Group screening: Negativistic* & 0.000 & 1 & .013 \\
\hline Knowledge about oneself: Name and surname ${ }^{* *}$ & 6.452 & 1 & .013 \\
\hline Knowledge about oneself: Age ${ }^{* *}$ & 10.286 & 1 & .002 \\
\hline Knowledge about oneself: Exact address* & 3.333 & 1 & .058 \\
\hline Knowledge about oneself: Parents' names ${ }^{* *}$ & 20.690 & 1 & $<.0001$ \\
\hline Speech, language and communication: Pronunciation* & 0.000 & 1 & 1 \\
\hline Speech, language and communication: Articulation & 12.500 & 1 & .0004 \\
\hline Speech, language and communication: Intensity of speech ${ }^{*}$ & 0.810 & 1 & .358 \\
\hline $\begin{array}{l}\text { Speech, language and communication: Problem } \\
\text { understanding instructions in the standard language }\end{array}$ & 20.513 & 1 & $<.0001$ \\
\hline Mathematical abilities: Ascending numerical series to 10 & 13.333 & 1 & .0002 \\
\hline Mathematical abilities: Descending numerical series from 10 & 13.333 & 1 & .0002 \\
\hline Mathematical abilities: Determining numbers up to 10 & 21.645 & 1 & $<.0001$ \\
\hline Mathematical abilities: Basic geometric shapes & 114.286 & 1 & $<.0001$ \\
\hline $\begin{array}{l}\text { Individual screening: Unable to separate from loved ones/ } \\
\text { acquaintances* }\end{array}$ & 0.000 & 1 & 1 \\
\hline Individual screening: Distracted/inattentive* & 0.000 & 1 & 1 \\
\hline Individual screening: Dependent/uncertain* & 0.966 & 1 & .345 \\
\hline Individual screening: Emotionally out of tune ${ }^{* *}$ & 6.452 & 1 & .013 \\
\hline Individual screening: Negativistic** & 6.452 & 1 & 0.013 \\
\hline
\end{tabular}

* There is no difference between the groups in the post-test.

** The experimental group of children was statistically worse at the output than the control group. 
Viera ŠILONOVÁ, Vladimír KLEIN, Ivana ROCHOVSKÁ. Inclusive diagnostics and stimulation of socially disadvantaged children of a pre-school age: Experimental verification

A further processing of the results of the post-test of the experimental group and the control group was carried out by a Pearson's Chi-square test to determine the relationships between two nominal variables. The test verified the null hypothesis, which states that the variables are independent. In the monitored 8 areas out of a total number of 22 measured areas in the post-test, a statistically significant difference was recorded between the performance of the children from the experimental group and the control group. The experimental group of children had statistically significantly worse results in the post-test than the control group of children, namely in 5 areas: By comparing the calculated values in 9 items out of the total number of 22 items, statistically significantly better results were recorded in the post-test in favour of children from the experimental group. These areas are: Group screening: Distracted/ inattentive; Group screening: Dependent/uncertain; Group screening: Emotionally out of tune; Speech, language and communication: Articulation; Speech, language and communication: Problem understanding instructions in the standard language; Mathematical abilities: Ascending numerical series to 10; Mathematical abilities: Descending numerical series from 10; Mathematical abilities: Determining numbers up to 10; Mathematical abilities: Basic geometric shapes.

From the 26 items in the area of symptoms ( 22 measured by Pearson's Chi-square and 4 measured by a $t$-test), 11 were statistically significantly better in favour of children from the experimental group. There was no difference between the groups in the post-test groups in 10 items and only in 5 measured areas were statistically significantly worse results recorded in the experimental group of children compared to the results of the control group of children.

Based on the results of this part of the research, the subhypothesis $\mathrm{SH}_{1.2}$ was adopted.

In order to determine the normality or abnormality of the distribution of the data needed for the subsequent verification of hypothesis 1, subhypotheses $\mathrm{SH}_{1.1}$ and $\mathrm{SH}_{1.2}$ and on the basis of the sample size, a paired $t$-test and Pearson's Chi-square test were used.

In hypothesis 1 and its subhypotheses $\mathrm{SH}_{1.1}$ and $\mathrm{SH}_{1.2}$, it was determined whether there was a statistically significant difference in the results of the post-test between the experimental group and the control group of children. Based on the results shown in Tables 4, 5 and 6, it can be stated that there is a statistically significant difference between the experimental and control groups in favour of the experimental group of children. Hypothesis 1 and subhypotheses $\mathrm{SH}_{1.1}$ and $\mathrm{SH}_{1.2}$ were adopted.

\section{Verification of Hypothesis $\mathrm{H}_{2}$}

Hypothesis $\mathrm{H}_{2}$ assumed that children in each group would be better in the post-test in at least one area than in the pre-test. Table 9 shows the results of the input and output measurements of the control group of children focused on the deficits of partial functions.

\author{
PROBLEMS \\ OF EDUCATION \\ IN THE $21^{\text {st }}$ CENTURY \\ Vol. 79 , No. 5, 2021 \\ 815
}


Viera ŠILONOVÁ, Vladimír KLEIN, Ivana ROCHOVSKÁ. Inclusive diagnostics and stimulation of socially disadvantaged children of a pre-school age: Experimental verification

\author{
PROBLEMS \\ OF EDUCATION \\ IN THE $21^{\text {st }}$ CENTURY \\ Vol. 79 , No. 5, 202 \\ Table 9 \\ Pre-test and Post-test Results of the Control Group (t-test)
}

\begin{tabular}{|c|c|c|c|c|c|c|}
\hline \multirow[t]{2}{*}{ Area } & \multicolumn{2}{|c|}{$M$} & \multirow[t]{2}{*}{$t$} & \multirow[t]{2}{*}{$p$} & \multicolumn{2}{|r|}{$S D$} \\
\hline & Control & Experimental & & & Control & Experimental \\
\hline $\begin{array}{l}\text { The drawing of a person (max. } \\
5 \text { points) }\end{array}$ & 2.63 & 3.69 & -2.565 & .016 & 1.36 & 0.95 \\
\hline $\begin{array}{l}\text { Visual differentiation of the } \\
\text { figure and the background, } \\
\text { only the picture with hens } \\
\text { (max. } 6 \text { errors) }\end{array}$ & 1.06 & 0.44 & 0.994 & .328 & 2.02 & 1.50 \\
\hline $\begin{array}{l}\text { Visual differentiation (max. } 6 \\
\text { errors) }\end{array}$ & 4.19 & 2.69 & 2.122 & .042 & 1.91 & 2.09 \\
\hline Visual memory (max. 6 errors) & 3.94 & 3.13 & 1.267 & .215 & 1.84 & 1.78 \\
\hline $\begin{array}{l}\text { figure and the background } \\
\text { (max. } 12 \text { errors) }\end{array}$ & 10.25 & 9.25 & 0.863 & .395 & 3.57 & 2.96 \\
\hline $\begin{array}{l}\text { Auditory differentiation (max. } \\
6 \text { errors) }\end{array}$ & 4.00 & 3.25 & 0.978 & .336 & 2.37 & 1.95 \\
\hline $\begin{array}{l}\text { Auditory memory (max. } 7 \\
\text { errors) }\end{array}$ & 3.56 & 1.69 & 3.181 & .003 & 1.93 & 1.35 \\
\hline $\begin{array}{l}\text { Tactile-kinesthetic perception } \\
\text { (max. } 6 \text { errors) }\end{array}$ & 3.75 & 3.13 & 0.794 & .433 & 2.32 & 2.13 \\
\hline Body diagram (max. 4 errors) & 3.00 & 3.00 & 0.000 & 1 & 1.21 & 1.15 \\
\hline $\begin{array}{l}\text { Intermodality: visual-auditory } \\
\text { (max. } 9 \text { errors) }\end{array}$ & 4.25 & 1.13 & 2.508 & .018 & 4.43 & 2.28 \\
\hline $\begin{array}{l}\text { Intermodality: auditory-visual } \\
\text { (max. } 9 \text { errors) }\end{array}$ & 5.69 & 4.19 & 1.153 & .258 & 3.75 & 3.60 \\
\hline Visual seriality (max. 5 errors) & 3.88 & 2.63 & 1.563 & .129 & 2.06 & 2.45 \\
\hline $\begin{array}{l}\text { Auditory seriality (max. } 5 \\
\text { errors) }\end{array}$ & 1.63 & 0.81 & 1.148 & .260 & 2.36 & 1.56 \\
\hline Vocabulary range & 8.81 & 9.31 & -0.411 & .684 & 3.06 & 3.79 \\
\hline Categorisation & 0.63 & 1.56 & -2.197 & .036 & 1.20 & 1.21 \\
\hline Size, quantity, order & 3.75 & 4.50 & -0.739 & .465 & 2.74 & 2.99 \\
\hline
\end{tabular}

The statistical significance between the input and output measurements of the performance of children from the control group in the area of deficits of partial functions was confirmed in three items. The results of the findings are as follows:

Through the calculated t-statistic (2.122), at a level of significance of 0.042 , a statistically significant difference was found between the results in the pre-test and post-test of the control group of children. In the output measurement, the control group achieved in the area of Visual differentiation a lower number of errors $(M=2.69)$ than in the input measurement $(M=4.19)$.

The control group achieved at output in the area of Auditory memory a lower number of errors $(M=1.69)$ than the control group at input $(M=3.56)$. A statistically significant difference between the input and output measurements was confirmed in favour of the output measurement $(t=4.533, d f=1, p<.0001)$ of the control group of children.

A statistically significant difference between the results of the post-test and the pre-test of the control group was found through the calculated $t$-statistic (2.508) at a level of significance of 0.018. In the post-test, the control group achieved in the area of Intermodality: visual-auditory a lower number of errors $(M=1.13)$ than in the pre-test $(M=4.25)$. From the twelve measured areas at input and output, the control group achieved statistically significantly better results in 3 items in the post-test. The pre-test and post-test results of the experimental group of children in the area of symptoms are shown in Table 10. 
Viera ŠILONOVÁ, Vladimír KLEIN, Ivana ROCHOVSKÁ. Inclusive diagnostics and stimulation of socially disadvantaged children of a pre-school age: Experimental verification

Table 10

Pre-test and Post-test Results of the Experimental Group (t-test)

\begin{tabular}{|c|c|c|c|c|c|c|}
\hline \multirow[t]{2}{*}{ Area } & \multicolumn{2}{|c|}{$M$} & \multirow[t]{2}{*}{$t$} & \multirow[t]{2}{*}{$p$} & \multicolumn{2}{|c|}{$S D$} \\
\hline & Pre-test & Post-test & & & Pre-test & Post-test \\
\hline $\begin{array}{l}\text { The drawing of a person (max. } 5 \\
\text { points) }\end{array}$ & 1.81 & 2.69 & -2.095 & .045 & 1.22 & 1.14 \\
\hline $\begin{array}{l}\text { Visual differentiation of the figure } \\
\text { and the background, only the } \\
\text { picture with hens (max. } 6 \text { errors) }\end{array}$ & 1.56 & 0.25 & 2.206 & .035 & 2.34 & 0.45 \\
\hline Visual differentiation (max. 6 errors) & 3.81 & 1.44 & 4.104 & $<.0001$ & 2.01 & 1.15 \\
\hline Visual memory (max. 6 errors) & 3.69 & 3.00 & 0.922 & .364 & 2.12 & 2.10 \\
\hline $\begin{array}{l}\text { Auditory differentiation of the figure } \\
\text { and the background (max. } 12 \\
\text { errors) }\end{array}$ & 9.69 & 5.00 & 4.925 & $<.0001$ & 3.03 & 2.31 \\
\hline $\begin{array}{l}\text { Auditory differentiation (max. } 6 \\
\text { errors) }\end{array}$ & 3.94 & 1.81 & 2.894 & .007 & 2.26 & 1.87 \\
\hline Auditory memory (max. 7 errors) & 3.81 & 1.44 & 3.382 & .002 & 2.56 & 1.15 \\
\hline $\begin{array}{l}\text { Tactile-kinesthetic perception (max. } \\
6 \text { errors) }\end{array}$ & 2.63 & 1.31 & 2.377 & .024 & 1.86 & 1.20 \\
\hline Body diagram (max. 4 errors) & 2.75 & 1.38 & 2.879 & .007 & 1.44 & 1.26 \\
\hline $\begin{array}{l}\text { Intermodality: visual-auditory (max. } \\
9 \text { errors) }\end{array}$ & 4.00 & 0.44 & 3.884 & .001 & 3.44 & 1.26 \\
\hline $\begin{array}{l}\text { Intermodality: auditory-visual (max. } \\
9 \text { errors) }\end{array}$ & 5.56 & 1.44 & 4.329 & $<.0001$ & 3.29 & 1.93 \\
\hline Visual seriality (max. 5 errors) & 3.44 & 0.94 & 3.895 & .001 & 1.86 & 1.77 \\
\hline Auditory seriality (max. 5 errors) & 1.63 & 0.31 & 2.345 & .026 & 2.13 & 0.70 \\
\hline Vocabulary range & 8.56 & 9.81 & -1.709 & .098 & 1.55 & 2.48 \\
\hline Categorisation & 0.81 & 2.25 & -3.105 & .004 & 0.91 & 1.61 \\
\hline Size, quantity, order & 3.00 & 6.88 & -5.580 & $<.0001$ & 2.16 & 1.75 \\
\hline
\end{tabular}

A statistical significance between the input and output measurements of the performance of children from the experimental group in the area of deficits of partial functions was confirmed in eleven items.

Through the calculated t-statistic (2.206), at a level of significance of 0.035 , a statistically significant difference was found between the results in the pre-test and post-test of the experimental group of children. In the output measurement, the experimental group achieved in the area of Visual differentiation of the figure and the background a lower number of errors $(M$ $=0.25)$ than in the input measurement $(M=1.56)$.

The experimental group achieved at output, in the area of Visual differentiation a lower number of errors $(M=1.44)$ than the same group at input $(M=3.81)$. A statistically significant difference between the input and output measurements was confirmed in favour of the output measurement $(t=4.104, d f=1, p<.0001)$ of the experimental group of children. 
Viera ŠILONOVÁ, Vladimír KLEIN, Ivana ROCHOVSKÁ. Inclusive diagnostics and stimulation of socially disadvantaged children of a pre-school age: Experimental verification

PROBLEMS

OF EDUCATION IN THE $21^{\text {st }}$ CENTURY Vol. 79 , No. 5,2021

818

A statistically significant difference between the results of the post-test and the pre-test of the experimental group was found through the calculated t-statistic (4.925) at a level of significance $p<.0001$. In the post-test, the experimental group achieved in the area of Auditory differentiation of the figure and the background a lower number of errors $(M=5.00)$ than in the pre-test $(M=9.69)$.

A statistical significance was also confirmed in the output measurement of the experimental group in the area of Auditory differentiation $(t=2.894, d f=1, p=.007)$. In the post-test, the experimental group had fewer errors $(M=1.81)$ unlike from the pre-test $(M=$ 3.94).

Through the calculated $t$-statistic (3.382), at a level of significance of 0.002 , a statistically significant difference was found between the results in the pre-test and post-test of the experimental group of children. In the output measurement, the experimental group achieved in the area of Auditory memory a lower number of errors $(M=1.44)$ than in the input measurement $(M=3.81)$.

A statistically significant difference between the pre-test and post-test results was also found in the item Tactile-kinesthetic perception $(t=2.377, d f=1, p=0.024)$. Children from the experimental group made fewer mistakes in the post-test $(M=1.31)$ than in the pre-test $(M$ $=2.63$ ).

The experimental group achieved at output in the area of Body diagram a lower number of errors $(M=1.38)$ than the same group at input $(M=2.75)$. A statistically significant difference between the input and output measurements was confirmed in favour of the output measurement $(t=2.879, d f=1, p=0.007)$ of the experimental group of children.

Through the calculated $t$-statistic (3.884), at a level of significance of 0.001 , a statistically significant difference was found between the results in the pre-test and post-test of the experimental group of children. In the output measurement, the experimental group achieved in the area of Intermodality: visual-auditory a lower number of errors $(M=0.44)$ than in the input measurement $(M=4.00)$.

A statistically significant difference between the input and output measurements in favour of the post-test of the experimental group was also found in the last three items: Intermodality: auditory-visual $(t=4.329, d f=1, p<.0001)$. In the aforementioned item, the experimental group achieved a lower number of errors in the post-test $(M=1.44)$ than in the pre-test $(M=5.56)$. Visual seriality $(t=3.895, d f=1, p=0.001)$. In the aforementioned item, the experimental group achieved a lower number of errors in the post-test $(M=0.94)$ than in the pre-test $(M=3.44)$. Auditory seriality $(t=2.345, d f=1, p=0.026)$. In the aforementioned item, the experimental group achieved a lower number of errors in the post-test $(M=0.31)$ than in the pre-test $(M=$ $1.63)$.

By comparing the results of the pre-test and the post-test in the experimental group of children focused on the area of deficits of partial functions, statistically significantly better results were found in the post-test, namely in 11 items out of a total number of 12 .

It was confirmed that both groups of children (control and experimental) achieved statistically significantly better results in the post-test, focused on the area of deficits of partial functions measured by a T-test, than in the pre-test. By analysing the results of this part of the research, subhypothesis $\mathrm{SH}_{2.1}$ was adopted.

The following is an analysis of the results of the input and output measurements of the items in the area of symptoms through a Pearson's Chi-square test in both groups. The results of the pre-test and the post-test findings in the control group are presented in Table 11. 
Viera ŠILONOVÁ, Vladimír KLEIN, Ivana ROCHOVSKÁ. Inclusive diagnostics and stimulation of socially disadvantaged children of a pre-school age: Experimental verification

Table 11

Pre-test and Post-test Results of the Control Group (Pearson's Chi-square test)

\begin{tabular}{|c|c|c|c|}
\hline Area & $\chi^{2}$ & $d f$ & $p$ \\
\hline $\begin{array}{l}\text { Group screening Unable to separate from loved ones/ } \\
\text { acquaintances* }\end{array}$ & 0.000 & 1 & 1 \\
\hline Group screening, Distracted/inattentive ${ }^{*}$ & 0.000 & 1 & 1 \\
\hline Group screening, Dependent/uncertain* & 0.000 & 1 & 1 \\
\hline Group screening, Emotionally out of tune ${ }^{* *}$ & 6.452 & 1 & .013 \\
\hline Group screening, Negativistic & 6.452 & 1 & .013 \\
\hline Knowledge about oneself - Name and surname & 13.333 & 1 & .0002 \\
\hline Knowledge about oneself - Age ${ }^{*}$ & 1.481 & 1 & .235 \\
\hline Knowledge about oneself - Exact address & 20.243 & 1 & $<.0001$ \\
\hline Knowledge about oneself - Parents' names & 46.154 & 1 & $<.0001$ \\
\hline Speech, language and communication - Pronunciation* & 3.333 & 1 & .058 \\
\hline Speech, language and communication - Articulation* & 3.636 & 1 & .054 \\
\hline Speech, language and communication - Intensity of speech ${ }^{*}$ & 0.000 & 1 & 1 \\
\hline $\begin{array}{l}\text { Speech, language and communication - Problem } \\
\text { understanding instructions in the standard language* }\end{array}$ & 0.000 & 1 & 1 \\
\hline Mathematical abilities - ascending numerical series to 10 & 38.431 & 1 & $<.0001$ \\
\hline Mathematical abilities - Descending numerical series from 10 & 6.452 & 1 & 0.013 \\
\hline Mathematical abilities - Determining numbers up to 10 & 47.343 & 1 & $<.0001$ \\
\hline Mathematical abilities - Basic geometric shapes* & 0.000 & 1 & 1 \\
\hline $\begin{array}{l}\text { Individual screening - Unable to separate from loved ones/ } \\
\text { acquaintances* }\end{array}$ & 0.000 & 1 & 1 \\
\hline Individual screening - Distracted/inattentive** & 7.143 & 1 & .005 \\
\hline Individual screening - dependent/uncertain** & 5.128 & 1 & .028 \\
\hline Individual screening - emotionally out of tune ${ }^{*}$ & 0.000 & 1 & 1 \\
\hline Individual screening - negativistic* & 0.000 & 1 & 1 \\
\hline
\end{tabular}

* The results of the pre-test and the post-test did not statistically significantly improve.

** In the post-test, the results are statistically significantly worse than in the pre-test.

The results of the pre-test and post-test of the control group were carried out through a Pearson's Chi-square test. In the monitored 12 items out of a total number of 22 measured areas, no statistically significant improvement in the performance of the children of the control group was recorded in the post-test. The control group of children had statistically significantly worse results in the post-test in 3 areas. By comparing the calculated values in 7 items out of a total number of 22 items, statistically significantly better results were recorded in the post-test of the control group. These areas are: Group screening, Negativistic; Knowledge about oneself, Name and surname; Knowledge about oneself, Exact address; Knowledge about oneself, Parents' 
Viera ŠILONOVÁ, Vladimír KLEIN, Ivana ROCHOVSKÁ. Inclusive diagnostics and stimulation of socially disadvantaged children of a pre-school age: Experimental verification

IN THE $21^{\text {st }}$ CENTURY Vol. 79 , No. 5, 2021

names; Mathematical abilities - Ascending numerical series to 10; Mathematical abilities Descending numerical series from 10; Mathematical abilities - Determining numbers up to 10.

From the 26 monitored items belonging to the area of symptoms (22 measured through a Pearson's Chi-square test and 4 measured by a $t$-test), there were 8 statistically significantly better items in the output measurement of the control group. Table 12 presents the results of the input and output measurements in the experimental group.

\section{Table 12}

Pre-test and Post-test Results of the Experimental Group (Pearson's Chi-square test)

\begin{tabular}{|c|c|c|c|}
\hline Area & $\chi^{2}$ & $d f$ & $p$ \\
\hline Group screening, Unable to separate from loved ones/acquaintances & 28.571 & 1 & $<.0001$ \\
\hline Group screening, Distracted/inattentive & 4.167 & 1 & .048 \\
\hline Group screening, Dependent/uncertain* & 0.966 & 1 & .345 \\
\hline Group screening, Emotionally out of tune & 28.571 & 1 & $<.0001$ \\
\hline Group screening, Negativistic & 20.690 & 1 & $<.0001$ \\
\hline Knowledge about oneself - Name and surname & 13.333 & 1 & .0002 \\
\hline Knowledge about oneself - Age $^{*}$ & 0.000 & 1 & 1 \\
\hline Knowledge about oneself - Exact address & 38.431 & 1 & $<.0001$ \\
\hline Knowledge about oneself - Parents' names & 8.696 & 1 & .003 \\
\hline Speech, language and communication - Pronunciation & 7.287 & 1 & .006 \\
\hline Speech, language and communication - Articulation* & 3.175 & 1 & .08 \\
\hline Speech, language and communication - Intensity of speech & 7.059 & 1 & .009 \\
\hline $\begin{array}{l}\text { Speech, language and communication - Problem understanding instructions in the } \\
\text { standard language }\end{array}$ & 28.571 & 1 & $<.0001$ \\
\hline Mathematical abilities - ascending numerical series to 10 & 37.500 & 1 & $<.0001$ \\
\hline Mathematical abilities - Descending numerical series from 10 & 28.571 & 1 & $<.0001$ \\
\hline Mathematical abilities - Determining numbers up to 10 & 94.902 & 1 & $<.0001$ \\
\hline Mathematical abilities - Basic geometric shapes & 78.125 & 1 & $<.0001$ \\
\hline Individual screening - Unable to separate from loved ones/acquaintances & 28.571 & 1 & $<.0001$ \\
\hline Individual screening - Distracted/inattentive & 14.545 & 1 & .0001 \\
\hline Individual screening - Dependent/uncertain* & 0.966 & 1 & .89 \\
\hline Individual screening - Emotionally out of tune & 28.571 & 1 & $<.0001$ \\
\hline Individual screening - Negativistic & 13.333 & 1 & .0002 \\
\hline
\end{tabular}

* The results of the pre-test and post-test did not statistically significantly improve.

The results of the pre-test and post-test of the experimental group were carried out by a Pearson's Chi-square test. In the monitored 4 items from the total number of 22 monitored areas, no statistically significant improvement in the performance of the children of the experimental 
Viera ŠILONOVÁ, Vladimír KLEIN, Ivana ROCHOVSKÁ. Inclusive diagnostics and stimulation of socially disadvantaged children of a pre-school age: Experimental verification

\author{
PROBLEMS \\ OF EDUCATION \\ IN THE $21^{\text {st }}$ CENTURY
}

group was recorded in the post-test. By comparing the calculated values in 18 items from a total number of 22 items, statistically significantly better results were recorded in the post-test of the experimental group. These areas are: Group screening, Unable to separate from loved ones/ acquaintances; Group screening, Distracted/inattentive; Group screening, Emotionally out of tune; Group screening, Negativistic; Knowledge about oneself, Name and surname; Knowledge about oneself, Exact address; Knowledge about oneself, Parents'names; Speech, language and communication - Pronunciation; Speech, language and communication - Intensity of speech; Speech, language and communication - Problem understanding instructions in the standard language; Mathematical abilities - ascending numerical series to 10; Mathematical abilities Descending numerical series from 10; Mathematical abilities - Determining numbers up to 10; Mathematical abilities - Basic geometric shapes; Individual screening - Unable to separate from loved ones/acquaintances; Individual screening - Distracted/inattentive; Individual screening - emotionally out of tune; Individual screening, negativistic.

In the experimental group, 4 items belonging to the area of symptoms were monitored by a paired $t$-test. Three of them (The drawing of a person, Categorisation and Size, quantity, order) were statistically significantly better in the post-test than in the pre-test.

By comparing the results of the pre-test and the post-test in the experimental group of children focused on the area of symptoms, statistically significantly better results were found in the post-test in 21 items from a total of 26 .

It was confirmed that both groups of children (control and experimental) achieved in the post-test focused on the area of deficits of partial functions, measured by the Pearson's Chisquare test, statistically significantly better results than in the pre-test. Through an analysis of the results of this part of the research, the subhypothesis $\mathrm{SH}_{2.2}$ was adopted.

The obtained data needed for a subsequent verification of hypothesis 2 and subhypotheses $\mathrm{SH}_{2.1}$ and $\mathrm{SH}_{2.2}$ used a paired $t$-test and a Pearson's Chi-square test.

By verifying hypothesis 2 and its subhypotheses $\mathrm{SH}_{2.1}$ and $\mathrm{SH}_{2.2}$, it was discovered if there will be a statistically significant improvement in the results of the post-test in both groups. By comparing the obtained data in the pre-test and the post-test of both groups (Table 12), it can be stated that both groups (control and experimental) have statistically significantly better results in the post-test than in the pre-test. For the purposes of the above, hypothesis 2 and subhypotheses $\mathrm{SH}_{2.1}$ and $\mathrm{SH}_{2.2}$ were adopted.

It was assumed that at the end of the experiment there would be a difference between the pre-test and the post-test performance in each of the groups, and at the same time that the difference would be higher in the experimental group (Table 12). Based on the presented results, it is possible to ascertain several significantly diverse differences in the experimental group. Therefore, it was confirmed that the effect of the independent variable was more significant than the standard course of education in the control group.

\title{
Discussion
}

According to a survey by the OECD (2020), the Slovak education system gives children the smallest chance of overcoming social inequalities, and this status is further deteriorating and is the most unfavourable among all 34 OECD countries. The Slovak Republic still ranks among the countries with an above-average degree of influence of the socio-economic background on the child's performance. If the child is from a poor family, he has only a minimal chance of obtaining a necessary education. Current statistics from the European Agency for Special and Inclusive Education (2020), show that the Slovak Republic belongs to the group of European Union member states with the highest proportion of children and pupils with special educational needs who are educated in segregated schools. 
Viera ŠILONOVÁ, Vladimír KLEIN, Ivana ROCHOVSKÁ. Inclusive diagnostics and stimulation of socially disadvantaged children of a pre-school age: Experimental verification

PROBLEMS

OF EDUCATION IN THE $21^{\text {st }}$ CENTURY Vol. 79, No. 5, 2021

822

Also, for the above reasons, the aim of the present research was to experimentally verify through input and output orientation diagnostics the effectiveness of the stimulation program for 5 to 6 year old socially disadvantaged children in kindergartens in Slovakia.

This research provided more details about the effectiveness of the stimulation program intended for the training of the areas of deficits of partial functions and symptoms in the experimental group.

The results of the research carried out among 92 kindergartens revealed that the socially disadvantaged children, who completed the stimulation program, achieved better results focused on the area of deficits of partial functions and the area of symptoms than socially disadvantaged children, who did not take part in the stimulation program. Children in each group had better results in the post-test focusing on the area of deficits of partial functions and the area of symptoms, than in the pre-test.

102 children from socially disadvantaged backgrounds took part in the input screening. From the stated number of respondents, 16 participants were randomly selected, who formed the experimental group. The limits of the research lie in the lower number of kindergartens involved in the output screening, which was caused by their closure due to the pandemic.

All hypotheses and subhypotheses were confirmed by the research. This is in line with the results of an effectiveness verification of the method within its standardisation in Austria, Switzerland and Germany. Children of a pre-school age were diagnosed and subsequently their training took place throughout the school year, according to the Sindelar methodology. At the end of the research, a rediagnostic was carried out, which proved the elimination of any deficits of partial functions among these children (Sindelar, 2009a, 2009b).

Similar results were found in a survey by the organisation, Human Development and Sustainable Development Teams, in 2014. The research has focused on diagnostics and counselling to support the inclusion of Romany people in Romania. As part of the results focused on pre-school education, the authors cited a study by Kendrall (2008), according to which Romany children, benefiting from pre-school and parental stimulation, had a significantly better output. Romany children aged 4 to 6, attending a pre-school facility in Romania, had more advanced skills in identifying ten letters of the alphabet, reading four simple common words, writing their name, distinguishing the numbers $1-10$, and recognising simple sentences in the national language. Groups of Romany children were compared, from which one group attended a local preschool and the other did not. The research has shown that disadvantaged groups attending a pre-school facility increases an individual's chances of achieving socioeconomic inclusion later in life.

Similar research results by Nowak, Bartusiak et al. (2009) have shown that the early detection of developmental disorders determines the need to take targeted stimulative and compensatory steps. Their scientific study represents a guide on how to detect symptoms of disorders in the psycho-motor development of preschool age children and how to implement an early intervention program within praxis.

The results of the research study entitled Children's Task Persistence in Relation to Stimulation at Home have shown that children from families with a low-income, who have less cognitive stimulation, completed fewer tasks compared to their peers from families with a high-income (Orr, 2020). The results are in line with the need for and the use of a stimulation program for socially disadvantaged children.

\section{Conclusions and Implications}

All children benefit from the practical implementation of an inclusive upbringing and education. Children with specific educational needs have the opportunity to observe and interact with peers, develop communication and social competencies acceptable to others and, in the process of social learning, acquire a set of important knowledge, skills and habits. 
Viera ŠILONOVÁ, Vladimír KLEIN, Ivana ROCHOVSKÁ. Inclusive diagnostics and stimulation of socially disadvantaged children of a pre-school age: Experimental verification

PROBLEMS

OF EDUCATION

IN THE $21^{\text {st }}$ CENTURY

Vol. 79, No. 5, 2021

As the inclusive upbringing and education of children requires teamwork, teachers must also acquire the skills needed to work with several specialists, especially in diagnosing the child's level of development, while creating individual educational plans for each child and their evaluation. At the same time, they are required to constantly innovate methodological procedures and improve their qualifications. The inclusive upbringing and education of children in kindergartens significantly contributes to the mutual knowledge of the children. Children learn about the strengths and weaknesses of their peers, learn to live together, and respect each other. Good interpersonal relationships are a prerequisite that will sustain them also in later life, which is a prerequisite for the coexistence of the entire community. Experience shows that inclusive educated children are generally better placed to become full and respected members of the community, thus improving the overall quality of life of the inhabitants of the community.

The research clearly confirmed that children who completed the stimulation program achieved better results than children from the control group who did not complete the stimulation program, both in the area of deficits of partial functions and in the area of symptoms. Furthermore, it was shown that the children in each group were better in the post-test in at least one area than in the pre-test, both in the area of deficits of partial functions and in the area of symptoms.

The aforementioned results may be useful for all those participating in an inclusive preprimary education. Implication for further research may be the enrichment of the aforementioned research findings, obtained through a quantitative inquiry about the qualitative research of education within an inclusive group of children in kindergartens.

\section{Acknowledgements}

The research was done as part of VEGA project No. 1/0522/19 "The creation of an inclusive environment in a kindergarten and inclusive approaches in the diagnostics and development stimulation of socially disadvantaged children".

\section{Declaration of Interest}

Authors declare no competing interest.

\section{References}

Ainscow, M., \& César, M. (2006). Inclusive education ten years after Salamanca: Setting the Agenda. European Journal of Psychology of Education, 3(21), 231-238.

Bakken, L., Brown, N., \& Downing, B. (2017). Early childhood education: The long-term benefits. Journal of Research in Childhood Education, 31(2), 255-269.

Hanson, J. L., Chandra, A. C., Wolfe, B. L., \& Pollak, S. D. (2011). Association between Incone and the Hippocampus. PLoS ONE, 6(5), Article e18712. https://doi.org/10.1371/journal.pone.0018712

Hul'ová, Z., Rochovská, I., \& Klein, V. (2018). The issue of age homogeneity in groups from the kindergartenteacher's perspective. The New Educational Review, 3(53), 203-215. https://doi.org/10.15804/tner.2018.53.3.17

Ishchenko, T., Hladush, V., Šilonová, V., \& Nikolenko, L. (2020). The usage of case method in preparation for teaching a foreign language. Journal of Critical Reviews, 17(7), 1506-1510. https://dx.doi.org/10.31838/jcr.07.17.190

Kendrall, S. et al. (2008). Narrowing the gap in outcomes for vulnerable groups. A review of the research evidencie. National Foundation for Educational Research.

Klein, V., Šilonová, V., \& Hladush, V. (2019). Actual problems of inclusion, integration of social and health disadvantaged pupils in the Slovak Republic. Kamianets-Podilsky, Ukraine: KamyanetsPodilsky National University. 
Viera ŠILONOVÁ, Vladimír KLEIN, Ivana ROCHOVSKÁ. Inclusive diagnostics and stimulation of socially disadvantaged children of a pre-school age: Experimental verification

\section{PROBLEMS \\ OF EDUCATION \\ IN THE $21^{\text {st }}$ CENTURY Vol. 79, No. 5, 2021 \\ 824}

Klein, V., Šilonová, V., \& Hladush, V. (2019). Formation of diagnostic and prognostic competence of the Master of Special Education. Ukraine Nation's Health, 2(55), 26-33.

Klein, V., Šilonová, V., \& Hladush, V. (2019). Tehnologija rannogo vtruchannja v inkljuzivnomu doshkilnomu zakladi osviti Slovachchini: dosvid, perspektivi [Early intervention in inclusive pre-school education in Slovakia: experiences, perspectives]. In Materiali $v$ Mizhnarodnoi naukovo-praktichnoï konferenciï Mizhnarodna naukovo-praktichna konferencija "Korekcijnoreabilitacijna dijal'nist': strategii rozvitku u nacionalnomu ta svitovomu vimiri" [A conference book from the scientific and practical conference "Corrective and rehabilitative activities: Strategies of development in national and global dimension"] (pp. 181-184). SumDPU.

Klein, V., Šilonová, V., \& Hladush, V. (2020). Individualnij pidhid u zabezpechenni psihologopedagogichnogo suprovodu inkljuzivnogo navchannja v shkolah Clovachchini: dosvid, perspektivi [Individual approach in psychological and pedagogical support of inclusive education in Slovakia: experiences, perspectives]. In L. V. Pomitkinoï, \& O. M. Ichanskoï (Eds.), Individualnist u psihologichnih vimirah spilnot ta profesij. III. Mizhnarodna naukovo-praktichna konferencija [Individuality in psychological dimensions of societies and professions. The 3rd internetional scientific and practical conference] (pp. 138-153). Al'fa-PIK.

Magnuson, K., \& Shager, H. (2010). Early education: Progress and promise for children from low-income families. Children and Youth Services Review, 32(9), 1186-1198.

Nikolenko, L., \& Šilonová, V. (2020). Cprijatlivij social'nij klimat v uchnivs'komu inkljuzivnomu kolektivi [Suitable social climate in inclusive team]. Ukraine: Ministry of Education and Science of Ukraine.

Nowak, A., Bartusiak, I., \& Romanowska-Tołłoczko, A. (2009). Diagnoza psychomotoryczna dzieci czteroletnich jako realizacja programu wczesnej interwencji w przedszkolach [Psychomotordiagnostics of four-years-old children as implementation of programme of early intervention in kindergartens]. Pediatria Polska [Polish Pediatry] 84(6), 517-523.

Orr, E. (2020). Children's task persistence in relation to stimulation at home. Early Child Development and Care, 190(11), 1725-1737.

Schröder, Xe., \& Schröder, U. (2000). Lernbehindertenpädagogik. Grundlagen und Perspektiven sonderpädagogischer Lernhilfe [Education of persons with learning disabilities. Basics and perspectives of special educational intervention]. Kohlhammer.

Sindelar, B. (2009a). Testtheoretische analyse und standardisierung des verfahrenszur erfassung von teilleistungsschwächen [Analysis of theoretical tests and standardization of process for recording of deficits of partial functions]. Elisabeth Unterfrauner Verlag Austria Press.

Sindelar, B. (2009b). Trainingsprogramme gegen Teilleistungsschwächen [Training programs focused on deficits of partial functions]. Verlag Austria Press GmbH.

Sindelar, B. (2014). Príručka k metodike na zachytenie čiastkových vývinových deficitov v spracovávaní informácii [A methodology manual for capturing partial developmental deficits in information processing]. Kanije Publishing House.

Šilonová, V., \& Klein, V. (2018). The diagnostics of socially disadvantaged pupils with learning difficulties - inclusive approach. In N. Bilousova, L. Dubrojevska, T. Gordjenko, \& V. Dubrovskij (Eds.), Visnik L'vovskogo Universitetu (pp. 488-500). Lvov: Seria pedagogična.

Šilonová, V., Klein, V., \& Hladush, V. (2019). Special education teacher in the kindergarten of the Slovak Republic. Ukraine Nation's Health, 2(55), 130-135.

Šilonová, V., Klein, V., \& Šinková, P. (2018). Manuál k depistáži pre deti predškolského veku pochádzajúce zo sociálne znevýhodneného prostredia - inovovaná čast' [A manual for screening children of a pre-school age from a socially disadvantaged background - innovated part]. Methodological and Pedagogical Centre in Prešov.

Šilonová, V., \& Klein, V. (2018). Edukácia sociálne znevýhodnených žiakov so špecifickými poruchami učenia [The education of socially disadvantaged pupils with specific learning disabilities]. Ružomberok, Slovakia: Verbum.

UNESCO (2009). Policy Guidelines on Inclusion in Education. UNESCO. 
Viera ŠILONOVÁ, Vladimír KLEIN, Ivana ROCHOVSKÁ. Inclusive diagnostics and stimulation of socially disadvantaged children of a pre-school age: Experimental verification

PROBLEMS

OF EDUCATION

IN THE $21^{\text {st }}$ CENTURY

Vol. 79, No. 5, 2021

825

Received: September 25, 2021

Accepted: October 10, 2021

Cite as: Šilonová, V., Klein, V., \& Rochovská, I. (2021). Inclusive diagnostics and stimulation of socially disadvantaged children of a pre-school age: Experimental verification. Problems of Education in the $21^{\text {st }}$ Century, 79(5), 804-825. https://doi.org/10.33225/pec/21.79.804

(Corresponding author)
Viera Šilonová

PhD, Lecturer, Faculty of Education, Prešov University in Prešov, 17. Novembra 15, 08001 Prešov, Slovakia.

E-mail: vierasilonova@gmail.com

ORCID: https://orcid.org/0000-0003-3347-925X

PhD, Professor, Faculty of Education, Prešov University in Prešov, 17. Novembra 15, 08001 Prešov, Slovakia.

E-mail: vladimir.klein@unipo.sk

ORCID: https://orcid.org/0000-0002-8895-0750

Ivana Rochovská
PhD, Associate Professor, Faculty of Education, Juraj Páleš Institute in Levoča, Catholic University in Ruzomberok, Bottova 15, 05401 Levoča, Slovakia.

E-mail: ikrupova@gmail.com

ORCID: https://orcid.org/0000-0001-9346-7993 